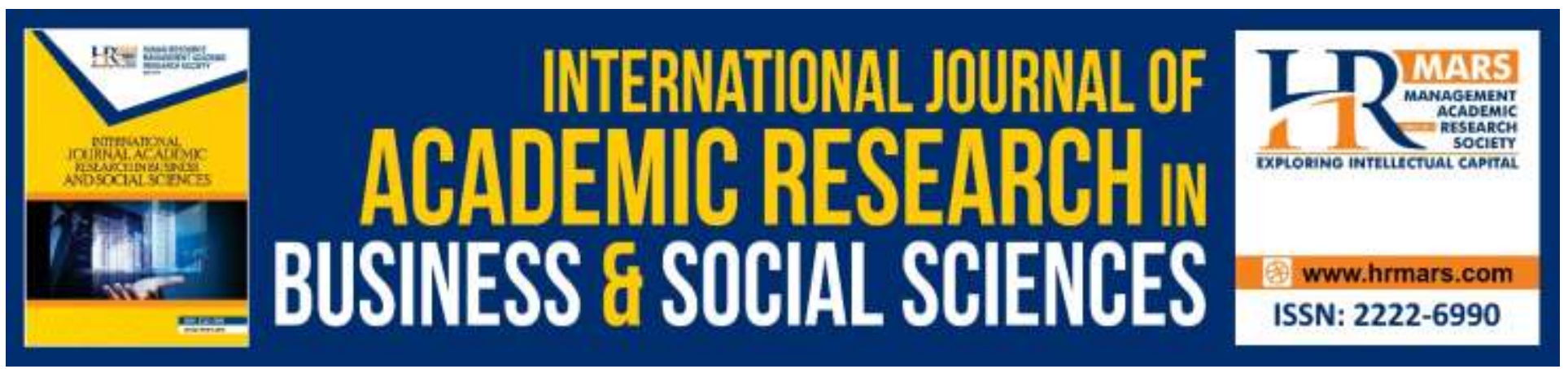

\title{
Difference in Entrepreneurial Intention on Generation X, Y and $Z$
}

Auditia Setiobudi and Christian Herdinata

To Link this Article: http://dx.doi.org/10.6007/IJARBSS/v8-i7/4323

DOI: 10.6007/IJARBSS/v8-i7/4323

Received: 04 June 2018, Revised: 19 June 2018, Accepted: 29 June 2018

Published Online: 18 July 2018

In-Text Citation: (Setiobudi \& Herdinata, 2018)

To Cite this Article: Setiobudi, A., \& Herdinata, C. (2018). Difference in Entrepreneurial Intention on Generation $\mathrm{X}, \mathrm{Y}$ and Z. International Journal of Academic Research in Business and Social Sciences, 8(7), 48-57.

Copyright: @ 2018 The Author(s)

Published by Human Resource Management Academic Research Society (www.hrmars.com)

This article is published under the Creative Commons Attribution (CC BY 4.0) license. Anyone may reproduce, distribute, translate and create derivative works of this article (for both commercial and non-commercial purposes), subject to full attribution to the original publication and authors. The full terms of this license may be seen at: http://creativecommons.org/licences/by/4.0/legalcode

Vol. 8, No. 7, July 2018, Pg. 48 - 57

http://hrmars.com/index.php/pages/detail/IJARBSS

JOURNAL HOMEPAGE

Full Terms \& Conditions of access and use can be found at

http://hrmars.com/index.php/pages/detail/publication-ethics 


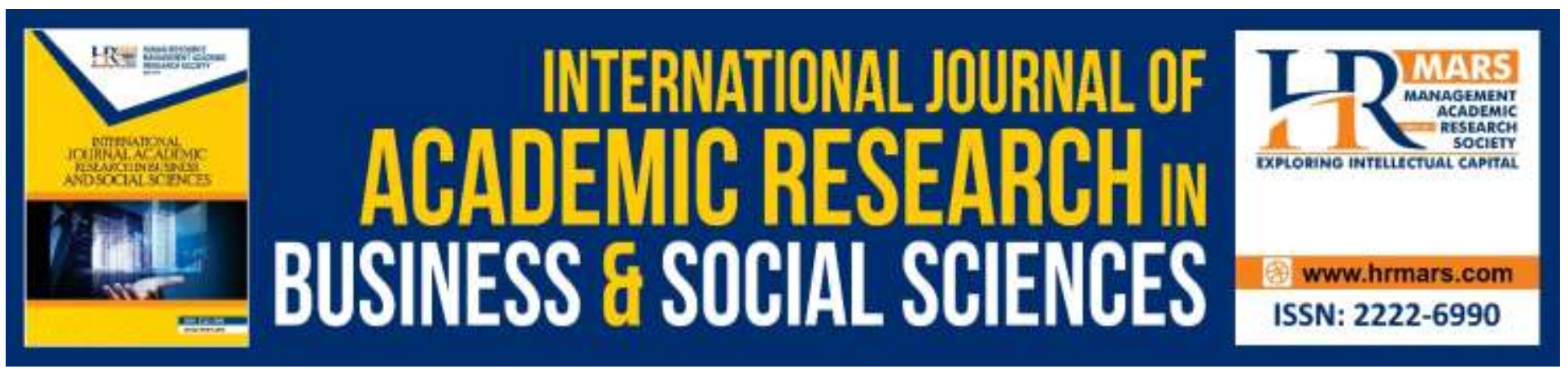

\title{
Difference in Entrepreneurial Intention on Generation $X, Y$ and $Z$
}

\author{
Auditia Setiobudi and Christian Herdinata \\ Universitas Ciputra, Surabaya, Indonesia
}

\section{Abstract}

The percentage of entrepreneurship in Indonesia has not reached two percent of the whole population. This is proven by the survey result of Global Entrepreneurship Monitor (GEM) which shows that, out of the total population of two hundred fifty million people, there is only $1.65 \%$ entrepreneur in Indonesia; this figure is still below other ASEAN countries. Nevertheless, the survey result says the perceived opportunity in Indonesia is rather high with $47 \%$ and the proportion of perceived opportunity between man (51\%) and woman (49\%) is similar. This shows that Indonesian people have high intention to become an entrepreneur. There are many businesses that grow from different generation backgrounds. Based on the generation theory, there are five generation groups which are categorized based on their birth cohort: Mature Generation (1925 - 1945), Boom Generation (1946 - 1964), Generation X (1965 - 1980) Millennial Generation (1981 - 2000), and Generation Z (2001 - present).

Previous researches have investigated the trend and characteristic of generations and entrepreneurial intention on a certain group. The objective of this research is to find out the trend of entrepreneurial intention on generation $\mathrm{X}$, millennial and $\mathrm{Z}$ based on the priority and perception on the need of achievement, self-efficacy, instrument readiness, demography and interest. The main objective of this research is to investigate the difference of entrepreneurial intention on the different generations. In the future, research will be developed to be applicable. Data were collected using questionnaire distribution regarding entrepreneurial intention on each generation with purposive sampling method and the collected data then analyzed using difference test.

Keywords: Intention, Entrepreneurial, Generation.

\section{Introduction}

The percentage of entrepreneurship in Indonesia has not reached two percent of the whole population. This is proven by the survey result of Global Entrepreneurship Monitor (GEM) which shows that, out of the total population of two hundred fifty million people, there is only $1.65 \%$ entrepreneur in Indonesia. (http://www.gemconsortium.org). This survey also shows that the percentage of entrepreneurs in Indonesia is still behind Singapore, Malaysia and Thailand, with 7\%, $5 \%$ and $3 \%$ respectively. Nevertheless, the survey result also says the eagerness of Indonesian people to become an entrepreneur is in the second position; Philippine is currently in the top position. The 
INTERNATIONAL JOURNAL OF ACADEMIC RESEARCH IN BUSINESS AND SOCIAL SCIENCES Vol. 8, No. 7, July 2018, E-ISSN: 2222-6990 @ 2018 HRMARS

perceived opportunity in Indonesia is rather high, which is $47 \%$, and the proportion of perceived opportunity between man (51\%) and woman (49\%) is similar. This shows that Indonesian people have high intention to become an entrepreneur.

Someone with an intention to start a business will be more ready and will produce a better progress for the business than someone who doesn't have any intention to start a business (Indarti, 2008). As stated by Krueger and Carsrud (1993), intention has been proven to be the best predictor for an entrepreneur. Therefore, intention can be used as the initial approach to understand who will become an entrepreneur (Choo and Wong, 2006).

There are many businesses that grow from different generation backgrounds. Some researchers expressed their individual opinion on the division of age in each generation. The main focus of this research is the entrepreneurial intention factor to generation $X, Y$ and $Z$ because these generations dominate the current era. Various researches on behavior tendency, comparison, and characteristic across generations have been frequently done. Generation theory on workforce is popularized by Strauss and Howe (2007), which states that generation will share some beliefs and similar behavior; a generation will also identify themselves as a different group compares to the other generations. This theory also identifies generation cycle in the United States history. In their research, Strauss and Howe (2007) grouped these generations into nineteen categories and mapped them based on their character and trend on every generation based on the phenomena that happen to the age group. Strauss and Howe's (2007) theory development talks about comparison on generation; research on this topic will be conducted by Mutjaba (2010), which focuses on cultural differences between generation $X$ and generation $Y$ in Thailand.

Some of the previous researches have reviewed the entrepreneurial intention on university students. One of these researches was done by Indarti and Rostiani (2008), which compares entrepreneurial intention on university students in three different countries. This research found that entrepreneurial intention influenced by different factors in each country. The analysis result shows variables that are tied to personality, instrument and demography together can significantly determine entrepreneurial intention although these variables together can only explain $28.2 \%$ for Indonesia, $14.2 \%$ for Japan and $24.8 \%$ for Norway. Gird and Bagraim (2008) under university student level found that attitude on entrepreneurship is a strong predictor to see an entrepreneurial intention.

This research is an expansion of the previous research done by Indarti and Rostiani (2008) which takes side on the entrepreneurial intention and the influential factors. The entrepreneurial intention studied here has a broader range, which is the entrepreneur across different generations The studied entrepreneurial intention factors consist of perception on accomplishment, self-efficacy, instrument readiness, demography and interest. This research has a new area of study, which is to identify the entrepreneurial intention factors based on mapping generation.

\section{Theory}

\section{Generation Theory}

Younger people have more energy and creativity than older people. Based on the research done by Sinha (1996) in India, almost every successful entrepreneur are the one that still relatively young. This complements the research done by Reynolds et al., (2000), which states that age 25-44 is the most-active age for someone to be an entrepreneur in the western countries.

The first generation theory was developed in the United States. Some researchers defined generations differently - but with a similar basis - which is a classification of years. Strauss and 
INTERNATIONAL JOURNAL OF ACADEMIC RESEARCH IN BUSINESS AND SOCIAL SCIENCES

Vol. 8, No. 7, July 2018, E-ISSN: 2222-6990 @ 2018 HRMARS

Howe(2007) defined generation as an aggregation of all people born within a range of twenty years or about one life-cycle long, which is from childhood, early adulthood, midlife to late adulthood. Furthermore, there are three criteria that have to be found in a generation: age location in history, common beliefs and behaviors, and common period membership.

The first criteria convey a meaning that the same generation will encounter key historical events and social trends at the same time. This lead to a generation that shares common beliefs and behaviors. Membership criteria mean a generation that identifies themselves as a different group from other generations. Hawkins (2007) stated that a generation is a group of age who has experienced common social life, political environment, history and economic events. This group experienced unique history, behavior and value.

Differences in generation, especially on the various definitions, have been widely discussed and reviewed in several scientific publications. Entrepreneurs and experts argue that the current generation of university students need different approach, in terms of education and training, to current employees in the firms. Various generations will be labelled differently because of the difference in specific generation classification.

Moreover, there is a disagreement among researchers regarding the age range that define one generation (Reeves and Oh, 2007); some researchers classify the year for each generation differently. Martin and Tulgan (2002) stated that Generation Y born in early 1987, while Howe and Starauss (2000) said this generation started by people born in 1982. However, both of them define the cut-off year for this generation as 2000. Oblinger and Oblinger (2005) and Tapscott (1998) divided and define generation into three, which are Baby Boom Generation (1946-1964), Generation X (19651975) and Digital Generation(1976-2000). Even Strauss and Howe (2007) classified generation into 19 different categories, started from the year of 1588. This research leads to the result by Tapscott (1998) who classified generation into 5 . The main focus which will be discussed is Generation X (19651976), Generation Y (1977-1997) and Generation Z (1998 until present).

\section{Needs and Achievement}

McClelland (1976) in Indart and Rostiani (2008) define achievement motivation as motivation that pushes someone to reach success by competing with a standard of excellence. This theory focuses on three needs, which are need for achievement, need for power and need for affiliation. Sengupta and Debnath (1994) on their research in India found that need for achievement has a big factor on an entrepreneur's level of success. It pushes the ability to take a decision and to be a risk taker. The higher the need for achievement for entrepreneurs, the more they can take the right decision. Moberg, C.R. and Leasher, M (2011) found that entrepreneur from the Western culture motivated more by need for achievement, affiliation and power than entrepreneur from the Eastern culture.

\section{Self-Efficacy}

Some researchers believe that self-efficacy has a strong bond with career development. Bandura (1986) in Indarti and Rostiani (2008) define self-efficacy as someone's belief in their own ability to finish a task. There are four ways to reach self-efficacy, which are (a) the experience of reaching success multiple times; (b) learning by observing; (c) social persuasions, like persuasive discussion and specific feedback; and (d) Valuation on self-psychology status. Referring to Betz and Hackett (1986), self-efficacy towards career is a domain that illustrates a personal opinion on someone's relationship with their career selection and adaptation process. Therefore, self-efficacy 
INTERNATIONAL JOURNAL OF ACADEMIC RESEARCH IN BUSINESS AND SOCIAL SCIENCES

Vol. 8, No. 7, July 2018, E-ISSN: 2222-6990 ㄷ 2018 HRMARS

can also be one of the most important factors in determining someone's entrepreneurial intention. Betz and Hacket also stated that as self-efficacy gets higher on entrepreneur who has just started their career, their entrepreneurial intention will get stronger.

\section{Instrument Readiness}

There are three environmental factors that are believed to influence entrepreneurship, which is access to capital, information and quality of social network. They are also called as instrument readiness (Indarti, 2004).

\section{Access to Capital}

Access to capital is a classic obstacle to starting a new business; this is at least true in developing countries with weak support from the financial institutions (Indarti, 2004). Based on the survey done previously, one of the biggest obstacles to start and grow a new business is the effort to obtain sufficient capital. Considering the importance of entrepreneurial on economic growth, then it is not surprising that the effort to alleviate this capital-for-entrepreneurs problem becomes an important goal for the policymakers around the world (Kerr and Nanda, 2009).

\section{Information Availability}

A Research done by Singh and Krishna (1994) proves that one of the main characteristics of an entrepreneur is to have a willingness to gain information. These activities to gain information are referring to the frequency of contacts someone makes from different sources. The result from this activity will depend on the availability of information through self-effort, social resources, dan network. New information availability depends on someone's characteristic, such as education level and quality of infrastructure which includes media coverage and telecommunication system (Kristiansen, 2002).

\section{Social Network}

Mazzarol et al. (1999) defined social network as relationship between two people that includes: (a) communication or information delivery from one party to another; (b) goods are services exchange from two parties; and (c) normative charges or expectations held by someone towards others because of the existing characters or special attributes. Kristiansen (2003) also mentioned a similar definition, which explains that social network composed by formal and informal relationship between the main and the supporting character in a connected circle and illustrates path for entrepreneurs to gain access to resources that they need to create, grow and reach success on their business.

\section{Demographic \\ Gender}

Schiller and Crawson (1997) found significant difference on business and entrepreneurial success between female and male. Michell and Walsh (2004) said that male and female have different wants in choosing their desired goods.

\section{Educational Background}

Based on Hansemark (1998), the main purpose of an entrepreneurship program is to develop the ability, knowledge, skill, attitude and completeness which are important for entrepreneurial 
INTERNATIONAL JOURNAL OF ACADEMIC RESEARCH IN BUSINESS AND SOCIAL SCIENCES

Vol. 8, No. 7, July 2018, E-ISSN: 2222-6990 @ 2018 HRMARS

activity. Heinonen \& Poikkijoki (2006) conclude there are three purposes of entrepreneurship education, which are learning to understand the meaning of entrepreneur, to show entrepreneur methods, and to become an entrepreneur.

\section{Work Experience}

Scott and Twomey (1988) researched about the work experience as a factor that can affect someone's perception towards a business and attitude towards their willingness to be an employee or entrepreneur. Further to this, it was mentioned that a conducive social environment condition and a positive work experience towards entrepreneurship will most certainly develop a good perspective towards entrepreneurship.

\section{Data and Methodology}

There are 3 steps in this research, which are to determine the population and sample, distribute questionnaire, and calculate and analyze the questionnaire results. The first step, prospective entrepreneurs in Indonesia is chosen to be the population target and prospective entrepreneurs from generation $X, Y$ and $Z$ (from Jogjakarta to Surabaya) is the sample target. The total of sample is 111 , with sample of 37 from each generation. The chosen sample provision in this research is based on Tapscott's (1998) generation theory of division of age. The sample was taken using judgement or purposive sampling and chosen based on several criteria used by the researcher (Remenyi, 2000). Purposive sampling technique was used to obtain representative and comparable result (Teddlie \& Yu, 2007). Judgement technique was used because the researcher clearly targeted sample characteristic, which are generation (age) and workers or students. From this, the desire of workers and students to become an entrepreneur will be investigated further.

The second step, researchers distributed the questionnaire. This questionnaire asks about the entrepreneurial intention that divided into 3 generations and measured from 6 variables that cover need for achievement, self-efficacy, instrumental readiness, demographic character, interest and leadership. The results were then measured using Likert 5-point scale. Information regarding demographic character, that consists of gender, also gathered through the answer from direct questions to obtain respondent description. The questionnaire distributions were done in-person to obtain higher return rate and to make sure the right person was targeted.

The data collection was done by completing forms and ensuring respondents' age, their condition - whether they are currently working or studying, and also desire to own a business. This technique was used to obtain respondents from different demographic backgrounds. The data collection was done from June to October 2017.

The third step is data calculation and analysis. Calculation of the questionnaire results was divided into 2 parts; firstly, calculate and test the different intention across entrepreneurial from generation $\mathrm{X}, \mathrm{Y}$ and $\mathrm{Z}$; secondly, the analysis of the intention between generations.

\section{Discussion}

This research is using division of generation which was written by the previous researcher, Tapscott (1998). The division of generation done by Tapscott (1998) is used as a reference because it is the first division of generation theory ever made and acts as the basis of growth to division of generation theory presently.

Based on the generation theory developed by Tapscott (1998), generation $\mathrm{x}$ is the one born in 1965 to 1976 with current (2017) age range of 52 to 41 years old; generation y, or the digital 
INTERNATIONAL JOURNAL OF ACADEMIC RESEARCH IN BUSINESS AND SOCIAL SCIENCES Vol. 8, No. 7, July 2018, E-ISSN: 2222-6990 (C) 2018 HRMARS

generation, is a group of people born in 1977 to 1997 at age range of 40 to 20 years old; lastly, generation z, or the net generation, is a group of people born in 1998 until present, with age range of 19 to 0 . Some of the theories also mention generation $Z$ as millennials generation because it is close to the start of the millennium year (2000).

\section{Difference Tests}

The tests were conducted to every generation and resulted in three findings. From the three tests, probability is the focus. Overall, the test results across generations show that there are differences and similarities between these three generations. The probability shown by Sig(2-tailed) calculation on every comparison variables on generation $X$ and $Z$ is less than 0.05 , which means there is a rather significant difference between these two. Some of the variables on the comparison between other generations (generation $Y$ and $Z$ and generation $X$ and $Y$ ) also show differences, however, some variables show similarities. This is demonstrated by the probability score of more than 0.05 . The main part of the questionnaire consists of multi-item scale questions related to the main variables. Several questions were used to measure behavioral questions to obtain a more accurate assumption on internal measurement level compare to if only one question was asked (Remenyi, 2000). Summaries of the respondent answers based on mean and comparison test on the differences across generations are shown below in table 1 and 2 .

Table 1. Summary of Respondent's Answers (Mean-based)

\begin{tabular}{|l|l|l|l|l|}
\hline \multicolumn{2}{|l|}{} & Generation X & Generation Y & Generation Z \\
\cline { 2 - 5 } Variables & Mean & Mean & Mean \\
\hline X1 for & $\begin{array}{l}\text { Need } \\
\text { achievement }\end{array}$ & 4,4865 & 4,3716 & 4,1892 \\
\hline X2 & Self-efficacy & 2,2432 & 2,1989 & 2,5957 \\
\hline X3 & $\begin{array}{l}\text { Instrument } \\
\text { readiness }\end{array}$ & 3,5130 & 3,4232 & 3,8927 \\
\hline X4 & Demography & 4,5000 & 4,3986 & 4,2386 \\
\hline X5 & Interest & 3,2335 & 3,6314 & 3,5686 \\
\hline
\end{tabular}


INTERNATIONAL JOURNAL OF ACADEMIC RESEARCH IN BUSINESS AND SOCIAL SCIENCES

Vol. 8, No. 7, July 2018, E-ISSN: 2222-6990 @ 2018 HRMARS

Table 2 Analysis Result of t-test

(Based On The Comparison Across Generations)

\begin{tabular}{|l|l|l|l|l|}
\hline \multirow{2}{*}{ Variables } & Generation X-Z & Generation Y - Z & Generation X-Y \\
\cline { 2 - 5 } & Sig (2-tailed) & Sig (2-tailed) & Sig (2-tailed) \\
\hline X1 & Need for achievement & 0,014 & 0,142 & 0,292 \\
\hline X2 & Self-efficacy & 0,019 & 0,009 & 0,790 \\
\hline X3 & Insturment readiness & 0,045 & 0,009 & 0,671 \\
\hline X4 & Demography & 0,015 & 0,146 & 0,318 \\
\hline X5 & Interest & 0,026 & 0,625 & 0,008 \\
\hline
\end{tabular}

The analysis result of t-test shows significant score or $\operatorname{Sig}(2$-tailed) $<0.05$ on the comparison of all variables on generation $X$ and $Z$. This shows that there are differences between these two, be it the priority and need for achievement, self-efficacy, instrument readiness, demography or interest.

This result is different from comparison between generation $Y$ and $Z$. The t-test result that shows significant score only evident on self-efficacy and instrument readiness. Need for achievement, demography, and interest show similarities on these two generations.

The significance score between comparison of generation $\mathrm{X}$ and $\mathrm{Y}$ shows only interest is different; the other variables have similarities. The analysis result shows that one of the generations perceive interest as a crucial point, but this is not apparent in the other generations.

\section{Conclusion and Suggestion \\ Conclusion}

There are obvious differences between generation $X$ and $Z$. The differences between generation $Z$ and $Y$ and generation $Y$ and $X$ also present, however, there are still some variables that show similarities between them. This happens because the age gap between generation $Y$ to $Z$ and $X$ are not big enough. Generation $\mathrm{Y}$ is still dominating both of the generations. Moreover, there are findings that show the big portion of respondents from generation $Y$ already has decent job; this is different to generation $Z$, as almost everyone is still studying. This same finding also apparent on generation $X$ as almost everyone is financially well-established. Another finding is only a small proportion of generation $Z$ have worked before, thus their knowledge in working life or entrepreneurship is not as high as the other 2 generations. From the result of difference test, there is no similarity between the 3 tests. 
INTERNATIONAL JOURNAL OF ACADEMIC RESEARCH IN BUSINESS AND SOCIAL SCIENCES Vol. 8, No. 7, July 2018, E-ISSN: 2222-6990 @ 2018 HRMARS

\section{Suggestion}

The research result shows that generation $X$ and $Z$ have the most contrast differences among the tested variables. It is explained in the discussion and conclusion that the cause of these differences is because of the diverse background. Therefore, the suggestion that can be made to other researchers is for them to use the result of this research as the basis for the development of other researches. Also, further investigations on other variables that can influence each of these generations to maintain their intention and interest to become an entrepreneur should be done.

The result of this research is expected to give a better illustration of the entrepreneurial intention across different generations. It is also expected that this research can be seen as an idea for universities and other institution to develop educational programs to foster the motivation of entrepreneurs.

\section{Corresponding Author}

Name $\quad$ : Auditia Setiobudi, S.E., MBA and Dr. Christian Herdinata, S.E., M.M., CFP ${ }^{\circledR}$

Affiliation : Universitas Ciputra Surabaya

Country : Indonesia

Email : auditia.setiobudi@ciputra.ac.id

Address : UC Town, Citraland, Surabaya, indonesia

\section{References}

Bandura, A. (1986). The Social Foundation of Tought and Action, Englewood Cliffs, NJ: Prentice Hall. Branston, C. (2006). From Game Studies to Bibliographic Gaming: Libraries Tap into the Video Game Culture. Bulletin of the American Society for Information Science and Technology, 32(4): 24-29.

Choo, S., Dan, M. W. (2006), "Entrepreneurial intention: triggers and barriers to new venture creations in Singapore". Singapore Management Review 28 (2): 47-64.

Gaith, G. (2010) An Exploratory Study of the Achievement of the Twenty-First Century Skills in Higher Education. Education \& Training, 52(6/7): 489-498.

Giles, M., Rea, dan A. (1970). "Career self-efficacy: an application of the theory of planned behavior". Journal of Occupational \& Organizational Psychology 73 (3): 393-399.

Hacket, G., Betz, dan N. E. (1986). "Application of self-efficacy theory to understanding career choice behavior". Journal of Social Clinical and Phsycology 4: 279-289.

Hansemark, O. (1998). The effects of a program on need for achievement and locus of control of reinforcement. International Journal of Entrepreneurship Behaviour and Research, 4, 28-50.

Harrell, A. M., Stahl, M. J. (1984). McClelland's Trichotomy of Needs Theory and the Job Satisfaction and Work Performance of CPA Firm Professionals. Accounting, Organizations and Society, 9 (34): 241-252.

Heinonen, J., \& Poikkijoki, S. (2006). An entrepreneurial-directed approach to entrepreneurship education: mission impossible. Journal of Management Development, 25,(80-94).

Howe, N., and Strauss, W. (2000). Millennials Rising: The Next Great Generation. New York: Vintage Books.

Indarti, N., (2004). "Factors affecting entrepreneurial intentions among Indonesian students". Jurnal Ekonomi dan Bisnis 19 (1): 57-70.

Indarti, N., dan Rostiani, R. (2008), Entrepreneurial Intentions among Student: Study Case of Indonesian, Japan, and Norwegian Students, Journal of Business and Economics, 23 (4). 
INTERNATIONAL JOURNAL OF ACADEMIC RESEARCH IN BUSINESS AND SOCIAL SCIENCES

Vol. 8, No. 7, July 2018, E-ISSN: 2222-6990 @ 2018 HRMARS

Kristiansen, S. (2001). "Promoting African pioneers in business: what makes a context conducive to small-scale entrepreneurship?". Journal of Entrepreneurship 10 (1): 43-69.

Martin, C. A., and Tulgan, B. (2002). Managing the Generational Mix. Amherst, MA: HRD Press.

Mazzarol, T., Volery, T., Doss, N., Thein, dan V. (1999). "Factors influencing small business start-ups". International Journal of Entrepreneurial Behaviour and Research 5 (2): 48-63.

McClelland, D. (1961). The Achieving Society, Princeton, New Jersey: Nostrand.

Moberg, C. R., Leasher, M. (2011). "Examining the differences in salesperson motivation among different cultures". American Journal of Business. 26(2): 145 - 160.

Oblinger, D., and Oblinger, J., Eds. (2005). Educating the Net Gen Washington, D.C.: EDUCAUSE.

Quester, P. G., dan Smart, J. (1998). The Influence of Consumption Situation and Product Involvement over Consumers' Use of Product Attribute. Journal of Consumer Marketing. Vol.15 Iss. 3, 220 238.

Reynolds, P. D., Hay, W. D., Bygrave, S. M. Camp, dan E. Aution, (2000). “Global entrepreneurship monitor: executive report". A Research Report from Babson College, Kauffman Center for Entrepreneurial Leadership, and London Business School.

Scott, M., Dan, D. T. (1988). "The long-term supply of entrepreneurs: students career aspirations in relation to entrepreneurship". Journal of Small Business Management 26 (4): 5-13.

Sinha, T. N. (1996). "Human factors in entrepreneurship effectiveness". Journal of Entrepreneurship 5 (1): 23-29.

Tapscott, D. (1998). Growing Up Digital: The Rise of the Net Generation. New York: McGraw-Hill.

Teddlie, C., \& Yu, F. (2007), Mixed Methods Sampling: A Typology with Examples. Journal of Mixed Method Research, 1(1): 77-100.

Walsh, G., Mitchell, V. W., Frenzel, T., dan Wiedmann, K. P. (2003), Internet-induced changes in consumer music procurement behavior: A German perspective, Marketing Intelligence \& Planning, Vol. 21, No. 5, hal. 305-317. 